ECOLOGICA, Vol. 28, No 101 (2021), 82-90

https://doi.org/10.18485/ecologica.2021.28.101.13

Originalni naučni rad

UDC:334.732:631.115.8

\title{
Zadrugarstvo kao nova paradigma održivog razvoja ruralnih područja u Srbiji
}

\section{Cooperatives as a new paradigm of sustainable development of rural areas in Serbia}

\author{
Slavka Mitrović ${ }^{1}$, Aleksandra Mitrović2 ${ }^{2}$ Ljubomir Mitrović ${ }^{3}$ \\ 1 Univerzitet u Prištini, Poljoprivredni fakultet, Lešak \\ ${ }^{1}$ University in Priština, Faculty of Agriculture, Lešak \\ 2,3Univerzitet u Prištini, Pravni fakultet, Kosovska Mitrovica \\ 2,3University in Priština, Faculty of Law, Kosovska Mitrovica \\ Rad primljen: 19.01.2021, Rad prihvaćen: 27.02.2021.
}

Sažetak: Zadrugarstvo u Srbiji ima dugu tradiciju, ali zadružni sektor nije razvijen, već je u privrednoj strukturi marginalizovan u poređenju sa razvijenim zadružnim sektorom zemalja EU. Zadružno organizovanje je imperativ modernog produktivnog privrednog razvoja i danas predstavlja predmet interesovanja svih vlada u svetu. Posebno je značajno za razvoj srednjeg i malog preduzetništva i od njega se očekuje više nego od profitnih organizacija. Zadrugarstvo može uticati na unapređenje održivosti sa tri aspekta: ekonomskog, sociološkog i ekološkog, ali ne samo zadruga i njenih članova, već i lokalnih i ruralnih područja u celini. Cilj rada je sagledavanje zadrugarstva i zadruga u unapređivanju održivog razvoja ruralnih područja u Srbiji. Najpre je definisana zadruga kao sui generis udruženje i ukazano je na postojanje njene pravne prirode. Zatim je definisan savremeni koncept ruralnog razvoja i pri tome analiziran je dosadađnji nivo ruralnosti, koji je veoma visok u Srbiji, te i mogućnosti za obnovu zapostavljenih ruralnih područja. Nadalje, istaknuta je istorijska uloga i značaj zadružnog pokreta u održivom razvoju sveta za XXI vek, što predstavlja savremeni izazov i u Srbiji. U posebnom delu ove problematike ukazano je da identitet zadruge predstavlja ugaoni kamen međaš za determinisanje zadruge kao posebnog privrednog lica i njeno razlikovanje od drugih subjekata. U poslednjem delu rada razmatra se sadašnje stanje u zadrugarstvu, a koje je definisano i uređeno Zakonom o zadrugama (2015). Istaknute su njegove dobre strane, ali i propusti koje bi trebalo otkloniti (posebno u delu o upravljanju zadrugom i osnivanju novih oblika zadruga), kako bi se povećali uloga i značaj zadrugarstva u jačanju održivog razvoja ruralnih područja u Srbiji.

Ključne reči: održivi razvoj, ruralni razvoj, poljoprivreda i ruralna ekonomija, zadruga i zadružni identitet, zadružni pokret, zadrugarstvo u Srbiji.

\footnotetext{
1'orcid.org/0000-0001-8569-2525, e-mail: slavka.mitrovic@pr.ac.rs 2orcid.org/0000-0003-1150-6907, e-mail: aleksandra.mitrovic@pr.ac.rs ${ }^{3}$ orcid.org/0000-0001-6740-0592, e-mail: ljubomir.mitrovic@pr.ac.rs
} 
Abstract: Cooperatives have a long tradition in Serbia, but the cooperative sector is underdeveloped, marginalized in the economic structure compared to the developed cooperative sector in EU countries. Organization through cooperatives represents an imperative of modern productive economic development and, nowadays, represents a subject of interest of all governments in the world. It is especially important for the development of small and medium companies and it entails more expectations that the profit organizations. Cooperatives may impact the improvement of sustainability from three aspects: economic, social and environmental, not only for the cooperatives and its members, but local and rural areas in whole. The goal of this paper is reviewing cooperatives related to the improvement of sustainable development of rural areas in Serbia. Primarily, cooperative has been defined as sui generis associations and its legal nature has been detailed. Then, modern concept of rural development has been defined with the analysis of current level of rural status, which is very high in Serbia, and the possibility of renewing neglected rural areas. Further, the historic role and significance of the cooperative movement has been pointed out in the sustainable development of the world for the XXI century, which is a modern challenge in Serbia as well. Separate section of this issue shows that the identity of the cooperative represents a corner stone of determining the cooperative as a special legal entity and its differentiation from other subjects. The last section of the paper considers current status of cooperatives, which is defined and regulated by the Law on Cooperatives (2015). Strengths and weaknesses that should be removed (especially in part related to management of cooperatives and establishment of new forms of cooperatives) of the Law were presented, in order to improve the role and significance of cooperatives in strengthening the sustainable development of rural areas in Serbia.

Keywords: sustainable development, rural development, agriculture and rural economy, cooperatives and cooperative identity, cooperative movement, cooperatives in Serbia.

\section{UVOD / INTRODUCTION}

Zadrugarstvo u Srbiji ima dugu tradiciju, ali zadružni sektor nije razvijen. Prolazilo je kroz različite periode uspona i padova, što je bilo rezultat istorijskog nasleđa i zakonske regulative, koja često nije išla u prilog zadrugarstvu. Zadruge „su tradicionalno najznačajniji oblik udruživanja i poslovnog organizovanja fizičkih i/ili pravnih lica, odn. zadrugara u cilju njihove ekonomske, socijalne, kulturne i ekološke održivosti. One su pravno lice i imperativ modernog, produktivnog privrednog razvoja, jer imaju bitne mogućnosti za povećanje racionalnosti i efikasnosti privređivanja i poslovanja“ (Mitrović et al., 2019) i danas predstavljaju predmet interesovanja svih vlada u svetu. Nesumnjivo, razvoj zadrugarstva omogući će oživljavanje srpskog sela, a tako će doći i do ravnomernijeg ruralnog razvoja, te je potrebno da se uključimo u trendove modernog zadrugarstva kakve poznaje EU i tako uklonimo barijere koje usporavaju razvoj i u Srbiji.

Činjenica je da je stepen ruralnosti u Srbiji visok, da je ona ruralna zemlja sa nedovoljno razvijenom poljoprivredom i izrazito zapuštenim ruralnim područjima, pa zadruge treba da ponovo postanu ne samo ekonomsko, već i kulturno, socijalno, psihološko i vaspitno središte razvoja sela. One treba da postanu „magnet“ za povratak ljudi iz gradova i inostranstva u sela (uz bolju infrastrukturu, zadružne domove, poštu, ambulantu, pristup internetu). Povratak na selo ne mora biti vezan za obradu zemlje, oni koji su se opredelili za život na selu mogu se uspešno baviti i nepoljoprivrednim delatnostima. Seoska područja mogu postati mesto za život visokoobrazovanih, kreativnih i talentovanih ljudi, s obzirom na to da oni traže da im mesto u kome žive i rade obezbedi poslovne izazove, profesionalno ostvarenje, ali i prijatno okruženje za život i odmor (Molnar, 2010). Opstanak na selu i povratak na selo za Srbiju je strateški značajno, jer sela se decenijama prazne, čak i potpuno nestaju.

Značaj zadružnog organizovanja posebno su prepoznale zemlje EU. One su razvojem zadruga rešile brojne probleme (socijalne i ekonomske). U Srbiji zadruge imaju veliki potencijal za održivi privredni i društveni razvoj, pa „one predstavljaju potencijal za oživljavanje poljoprivrede, ruralni i lokalni ekonomski razvoj" (Tomić et al., 2017). U ruralnim područjima poljoprivreda je veoma značajna za proizvodnju hrane, ali ne više sa stanovišta zaposlenja ruralne populacije, već sa aspekta zaštite životne sredine i prirodnog nasleđa.

\section{MATERIJALI I METODE / MATERIALS AND METHODS}

Cilj ovog rada je sagledavanje zadrugarstva i zadruga u unapređenju održivog razvoja ruralnih područja u Srbiji. Analiza koja ima za cilj ocenu dosadašnjeg stanja i moguće novine u zadrugarstvu, u unapređenju održvog razvoja ruralnih područja u Srbiji, zasnovana je na relevantnim podacima iz predmetne analize. Evidentno je u radu da je najveći broj podataka preuzet iz jedinstvene baze podataka RZS (popisi stanovništva i poljoprivrede, statistički godišnjaci). Kao osnovni izvori za istraživanje tretiranog problema su: Zakon o zadrugama Republike Srbije (2015), Uredba Evropske zadruge, Deklaracija o zadružnom 
identitetu i rezultati istraživanja nekih autora. Kada je reč o analizi zadrugarstva u unapređenju održivog razvoja ruralnih područja u Srbiji, korišćene su sistematska i komparativna analiza, kao i deskriptivna statistika koja je omogućila praćenje razvojnih tendencija u zadrugarstvu i kretanje ruralnog i urbanog stanovništva u Srbiji. Od klasičnih metoda primenjene su: analiza, sinteza, induktivna i deduktivna metoda.

\section{REZULTATI I DISKUSIJA / RESULTS AND DUSCUSSION}

\section{Pravna priroda zadruge / Legal nature of cooperatives}

Jedno od osnovnih pitanja na koje su pravna teorija i poslovna praksa pokušale da odgovore jeste pravna priroda zadruge. Ovo pitanje je ponovo aktuelno, s obzirom na reformske promene $u$ srpskoj privredi, odn. u zadružnom sektoru. Imajući u vidu da je zadruga definisana kao forma društva (udruženja), ili kao sui generis (jedinstveno) udruženje (Vitez, 1998), to se i organizuje u skladu sa osnovnim pravilima njenog organizovanja i rada zadružnim načelima, koja su važeća za sve vrste zadruga (u svim delatnostima) i na kojima se zasniva njen pravni položaj. Zato „razumevanje i očuvanje zadružnih principa je značajno ne samo u cilju definisanja zadružnih identiteta, već i zbog toga što od njih zavisi i uspeh zadruga na današnjem tržištu“ (Zakić, Nikolić, 2019). U savremenim uslovima privređivanja zadruga je posebna pravna forma $u$ oblasti zadrugarstva sa pravnim subjektivitetom, sa tendencijom da sve više poprima pojedine elemente društva kapitala (Hanrÿ, 2001). U poslednje dve decenije zadružno pravo u Srbiji je podleglo izmenama, da bi se usaglasilo sa principima slobode preduzetništva, osiguralo da zadruga ima istu poziciju u odnosu sa ostalim privrednim subjektima, odnosno pravno-ekonomskim entitetima, kao i da pruži dodatne mogućnosti za stvaranje sopstvenog kapitala. Naime, zadruga ima ograničen pristup izvorima kapitala, s obzirom na to da $u$ našem pravu zadrugu karakteriše visok stepen zatvorenosti poslovanja, što ukazuje na njene samopomoćne funkcije (ZOZ, 2015, čl. 54). Kada je reč o finansiranju zadruga ne postoje u našem zadružnom pravu štedno-kreditne zadruge koje predstavljaju najvažniji izvor finansiranja zadruga u razvijenim zemljama (isto, čl. 10). Takođe, po našem Zakonu o zadrugama (2015) zadruga ne može biti organizovana kao privredno društvo, niti se može pridružiti ili spojiti sa privrednim društvom (kompanijom), ili nekim drugim pravnim licem (entitetom) koje nije zadružnog karaktera, niti promeniti formu u privredno društvo, ili drugo pravno lice (entitet) (isto, čl.
5, st. 2). Zadružna načela na kojima počiva tradicionalna (klasična) zadruga, gde je i naša zadruga, daju potvrdu o pravnoj prirodi zadruge i ona nisu u saglasnosti sa izmenjenim zadružnim načelima, koja se uglavnom mogu naći u Uredbi EU 1435/03 (Uredba o Statutu Evropske zadruge, 2006), a čiji je cilj da se važeća načela o zadruzi približe odgovarajućim koja su primenljiva na preduzeća.

Uporednom analizom Uredbe Statuta Evropske zadruge (SCE) i važećeg domaćeg Zakona o zadrugama (2015), može se zaključiti da, iako postoje neke sličnosti, pa čak i neki delovi koji ostvaruju visok stepen saglasnosti - naš Zakon o zadrugama znatno ne odgovara ideji i duhu sadržanom u Statutu Evropske zadruge. Naime, u pogledu forme Evropske zadruge i zadruge u domaćem pravu postoje određene sličnosti: obe su pravna lica i za svoje obaveze odgovaraju svom svojom imovinom, dok osnivači odgovaraju samo do visine uplaćenog kapitala, osim ukoliko pravilima nije drugačije određeno. Osnivanje Evropske zadruge i domaće zadruge nije moguće bez uloga. U Evropskoj zadruzi minimalni osnivački kapital je $30.000 €$ (Uredba, čl. 33 , st. 1 i 2), a kod domaće zadruge 100 dinara (ZOZ 2015, čl. 21). Ulozi zadrugara kod Evropske zadruge, kao i kod domaće zadruge ne moraju biti jednaki. Najveću sličnost sa Statutom Evropske zadruge domaći zakon ima u odredbama o statutu zadruge. Prema domaćem pravu zadruga stiče svojstvo pravnog lica upisom u registar koji vodi organ nadležan za poslove registracije privrednih subjekata (ZOZ 2015, čl. 5, st. 2). Evropska zadruga upisuje se u sudski registar one države u kojoj ima svoje sedište, u skladu sa nacionalnim propisima o registraciji akcionarskih društava koji se primenjuju i pri objavi odgovarajućih upisa u sudski registar (Uredba, čl. 11 i 12).

Osnovna razlika između domaće i Evropske zadruge je u formiranju zadruga. Zadrugu u Srbiji mogu da osnuju samo fizička lica (najmanje 5 poslovno sposobnih fizičkih lica), dok Evropska zadruga može da nastane: osnivanjem novog pravnog lica na precizno determinisane načine ili transformacijom postojećih zadruga, takođe pod određenim uslovima. Značajne razlike su u odredbama koje regulišu glasačka prava članova. Domaće pravo određuje da svaki zadrugar ima jedan glas, dok se Statutom SCE predviđa da član može imati i više glasova. Kada je reč o odredbama o raspodeli dobiti u domaćem zadružnom pravu i Statutu SCE uglavnom zavise od zadružnih pravila. Prema domaćem zadružnom pravu dobit se raspodeljuje u rezervni fond, odn. fondove različite namene, ako su obrazovani, što znači da je ovaj fond neobavezujući i opcioni (ZOZ 2015, čl. 58, st. 
2 i čl. 59, par. 2, st. 2). Uredba, odn. Statut Evropske zadruge propisuje obavezu stvaranja zakonskih rezervi, koje se popunjavaju iz dobiti zadruge (Uredba, čl. 65). Za postupak prestanka, likvidacije i stečaja Evropske zadruge raspodela sredstava se vrši prema nacionalnom zakonu zemlje u kojoj zadruga ima registrovano sedište (Uredba, čl. 72), što je složeniji problem upoređivanja sa domaćim zadružnim pravom. Ističemo da od usvajanja Uredbe, tj. Statuta Evropskog zadružnog društva (SCE) 2003. on je postao obavezan za sve zemlje članice, a i za zemlje kandidate (među njima je i Srbija) sa momentom njihovog prijema u EU. Napominjemo da je ovaj dokument pravni instrument na osnovu kojeg se položaj zadruge izjednačava sa položajem drugih privrednih subjekata, pravnih lica, pri čemu omogućava konkurentni nastup zadruge na jedinstvenom globalnom tržištu.

Savremeni koncept ruralnog razvoja i stanje u Srbiji / Modern concept of rural development and situation in Serbia

U savremenoj teoriji i praksi postoje dva pristupa ruralnom razvoju: sektorski, odn. poljoprivredni i teritorijalni pristup, odn. ruralna ekonomija. Pre nego što istaknemo specifičnosti jednog i drugog koncepta treba definisati sâm pojam ruralno. Sa ekonomskog stanovišta možemo reći da je ruralno - teritorija koja se koristi za proizvodnju, dok je sa sociološkog stanovišta to sredina koju karakteriše zaostalost u poređenju sa tehnološkim i kulturnim razvojem u urbanoj sredini. Treba razlikovati pojam ruralno od pojma ruralnost: ruralno se odnosi na određeni geografski prostor, a ruralnost na specifično ponašanje u tom geografskom području (Humphreys, Rolley, 1991). U Srbiji nema integralne ruralne politike, jer je agrarna politika usmerena uglavnom na poljoprivredu, dok u razvijenim zemljama (EU) egzistira drugi pristup, tj. teritorijalni pristup koji se drugačije naziva ruralna ekonomija. Uglavnom korišćeno obeležje za definisanje ruralnih i urbanih naselja je broj stanovnika, ali se pri razgraničenjima razlikuju pragovi i intervali koji se definišu kao uslov (Mitrović et al., 2018). Saglasno metodologiji OESD-a, koja u kategoriju ruralnih područja na lokalnom nivou svrstava ona područja čija je gustina naseljenosti ispod 150 stanovnika po $\mathrm{km}^{2}$, dobija se podatak prema kojem se $85 \%$ teritorije Srbije identifikuje kao ruralna područja, u kojima živi 40,6\% stanovništva (Bogdanov, Babović, 2014). -Činjenica je da u ruralnim područjima Srbije danas dominira poljoprivreda, pa otuda učešće poljoprivrede u BDP-u poslednjih godina kreće se između 10 i $11 \%$, i pri tome Srbija se nalazi na četvrtom mestu u Evropi, a veće učešće imaju zemlje regiona: Albanija, Severna Makedo- nija i Crna Gora. Imajući u vidu stanje srpske poljoprivrede, visoko učešće poljoprivrede u BDP Srbije posledica je pre svega niskog nivoa razvijenosti drugih delatnosti, a ne visokoproduktivne poljoprivrede. Kada je reč o konceptu ruralna ekonomija treba istaći da je njegova suština u tome da je ruralna ekonomija po svom obimu iznad agrarnog (poljoprivrednog) koncepta razvoja, jer ne podrazumeva samo razvoj poljoprivrede, već i nepoljoprivrednih sektora, kao i svih delatnosti na ruralnom području. Uloga i značaj nepoljoprivrednih delatnosti na određenom području definisanom kao ruralni region su veoma veliki. Među tim delatnostima su: zanatstvo, turizam, trgovina, zdravstvo, šumarstvo, vodoprivreda i ribarstvo, zaštita životne sredine, kultura, prerađivačka industrija, bankarstvo, telekomunikacije, informatička tehnologija i brojne aktivnosti vezane za poboljšanje kvaliteta života stanovnika u ruralnim područjima. Savremena poljoprivredna proizvodnja je produktivna i intenzivna, ali je usmerena prema multifunkcionalnom razvoju ruralnih područja. Činjenica je da ruralna područja u Srbiji imaju značajne prirodne resurse za poljoprivredni ruralni razvoj. Međutim, do razvoja nije došlo i zato su neophodna određena restruktuiranja u ovoj oblasti, da bi se prevazišli mnogi problemi (Mitrović et al., 2018). Zato kao model budućeg razvoja Srbije opredeljujemo se za koncept razvoja održive poljoprivrede (ruralna ekonomija), koji poljoprivredu stavlja u širi kontekst, gde poljoprivreda ima funkciju ne samo $u$ ishrani stanovništva, već i ekonomsku funkciju, funkciju podrške razvoju turizma, socijalnu funkciju, kulturnu i funkciju očuvanja životne sredine i dugoročno održivog gazdovanja resursima (ibid.). Zapravo, racionalno korišćenje poljoprivrednih (prirodnih) resursa i zaštita i unapređenje životne sredine jedan je od nacionalnih prioriteta za dostizanje održivog razvoja u Srbiji.

Na konstataciju da Srbija ima visok nivo ruralnosti ukazuju i sledeći pokazatelji. Od ukupno 4709 naselja (bez 1449 na Kosovu i Metohiji) status grada ima 167, a ostala 4542 naselja (seoska kao dominantna, varošice i ostali tipovi) pretežno su ruralna. $U$ vangradskim naseljima živi 2.914 .000 stanovnika (RZS, 2017), tj. 40,6\% i prosečna gustina naseljenosti u ruralnim područjima je $63 \mathrm{st} / \mathrm{km}^{2}$, a u urbanim sredinama znatno je bolja $-289 \mathrm{st} / \mathrm{km}^{2}$. Proces deagrarizacije poljoprivrednog stanovništva u Srbiji išao je veoma dinamično. Naime, od ukupno 4709 naselja 1200 sela je u fazi nestajanja; u $86 \%$ naselja opada broj stanovnika; u 1034 sela je manje od 100 stanovnika; u 550 sela ima manje od po 5 stanovnika; u naseljima se nalazi 50.000 praznih kuća; na još 15.000 kuća piše da trenutno u njima 
niko ne živi; oko 50 je praznih naselja, a u $85 \%$ njih ima manje od po 10 stanovnika (Gulan, 2019). Tako, u periodu 2002-2011. godine nastavljen je pad učešća mladih uz istovremeno povećanje učešća starijih lica. Naime, „svaki peti stanovnik sela u Srbiji stariji je od 65 godina, dok je u regionu Južne i Istočne Srbije to svaki četvrti. Koeficijent starosne zavisnosti u ruralnim područjima, izuzimajući područje Vojvodine, ukazuju da na svakog stanovnika starijeg od 65 godina dolazi troje ili manje onih u dobu 15-65 godina. $S$ druge strane, odnos mladog i starog stanovništva pokazuje da na svakih 100 stanovnika starijih od 65 godina dolazi samo 69 onih do 15 godina (u Južnoj i Istočnoj Srbiji samo 52)" (Bogdanov, Babović, 2014). Takođe, nosilaca gazdinstava starijih od 50 godina u 2002. godini bilo je $44,3 \%$, a u 2012. povećalo se na $63,2 \%$. Činjenice koje dopunjuju pokazatelje nivoa ruralnosti Srbije je i broj poljoprivrednih gazdinstava.

Podaci pokazuju da su poljoprivredna gazdinstva u opadanju, i to sa 779.000 u 2002. na 631.552 u 2012. godini, tj. za oko 20\% (RZS, 2013). Poljoprivreda Srbije zasniva se na malim porodičnim gazdinstvima sa niskom produktivnošću rada i malim viškovima u proizvodnji. Pored toga, starenje seoskog stanovništva dovodi i do izumiranja mnogih tradicionalnih zanata, što nepovoljno utiče na očuvanje kulturne baštine. „Popisom poljoprivrede u Srbiji je registrovano ukupno 628.552 porodična gazdinstva i 1.416 .349 lica koja su angažovana na poljoprivrednim poslovima, u svojstvu članova gazdinstva ili stalno zaposlenih na gazdinstvu“ (Bogdanov, Babović, 2014).

Treba reći da je siromaštvo u ruralnim sredinama dva puta veće nego u urbanim. Smatra se da je svaki sedmi ruralni stanovnik siromašan. Pored toga, prisutno je loše upravljanje prirodnim resursima u ruralnim područjima, što se loše odražava na efikasno korišćenje resursa, kao i na narušavanje održivosti prirodne sredine.

\section{Zadružni pokret i zadružni identitet kao paradigma održivog razvoja / \\ Cooperative movement and cooperative identity as a paradigm of sustainable development}

Zadrugarstvo i zadružni pokret u Srbiji imaju dugu tradiciju (126 godina od osnivanja prve kreditne zemljoradničke zadruge u selu Vranovo kod Smedereva). Prolazilo je kroz periode uspona i padova, što je rezultat istorijskog nasleđa i zakonske regulative, koja često nije išla u prilog zadrugarstvu. Zadružni pokret u Srbiji do II svetskog rata bio je jedan od najrazvijenijih i najnaprednijih zadružnih pokreta, u Evropi i u svetu. Posle II svetskog rata, uspostavljanjem socijalističkog poretka i uvođenjem koncepta podruštvljavanja poljoprivrede, broj i značaj zadružnih pokreta znatno je opao. Uništavanje uspešnog zadružnog pokreta u Srbiji otpočelo je kolektivizacijom (seljačkih radnih zadruga) i ustavnim poništavanjem zadružne svojine, nasleđene od predratnih zadruga (ustavni zakon iz 1953). Tada je zadružna imovina pretvorena u društvenu svojinu. Ipak, stanje zadružnog pokreta u Srbiji nakon pada socijalističkog režima govori da ima potencijala koji nisu dovoljno iskorišćeni (u modernizacijskim promenama). Farmeri (poljoprivredna gazdinstva) su ti koji ubuduće treba da doprinesu jačanju zadružnog pokreta. On predstavlja pokret za sva vremena, što i znači da zadrugarstvo, odn. zadružni sistem organizovanja danas nije prevaziđen. Naprotiv, veoma je poželjan, posebno u organizaciji poljoprivredne proizvodnje, prerade i prometa prehrambenih proizvoda. Taj argument ide u prilog reafirmaciji zadružnog pokreta u Srbiji, i to pre svega zemljoradničkog zadrugarstva, kao najefikasnijeg leka protiv opasne demografske boljke - odumiranja sela. Zato zadruge treba ponovo da postanu ekonomsko, kulturno, vaspitno i socijalno središte razvoja sela. Posebno su značajne za očuvanje teritorijalnog integriteta naše države. One su vrlo značajne u brzom zaposlenju radne snage, posebno u „uslovima krize, zadruge rešavaju probleme zaposlenosti i poslovanja na efikasniji način nego komercijalne kompanije" (Borzaga, Galera, 2020). Prema podacima Međunarodnog zadružnog saveza, negativne efekte ekonomske krize najmanje je osetio zadružni sektor, što je još jedan od razloga za potrebu širenja zadružnog organizovanja u svim delatnostima. Zadrugarstvo kao model ekonomske, društvene i ekološke održivosti, posle globalne krize 2008. aktivno se propagira u razvijenim zemljama sveta. Zadruga od postanka do danas konstantno se prilagođava novonastalim uslovima i može da preuzme neka efikasnija i naprednija rešenja od drugih privrednih subjekata (uvodi nova pravila, pojmove, kategorije - menadžerske osobine, snaga umrežavanja, praćenje delovanja tržišta i dr.). $\mathrm{Na}$ taj način, promene koje dolaze sa evolucijom zadruge proširuju i osnažuju zadrugu kao specifičnog privednog subjekta, ali se time ne menja zadružna bit. Naime, ona nikada ne napusta svoj identitet koji počiva na tri stuba: ekonomski, socijalni i ekološki. Identitet zadruge čine tri ključne komponente: definicija zadruge, zadružne vrednosti i zadružni principi. U nastavku govorićemo o ovim komponentama.

a. Definicija zadruge. Postoje brojne definicije zadruge, ali veoma široka, načelna definicija koja 
može obuhvatiti sve specifičnosti posebnih vrsta zadruge jeste ona data u Dekleraciji o zadružnom identitetu, koju je 1995. usvojio Međunarodni zadružni savez (alijansa). Preporuka UN, Međunarodne organizacije rada (ILO Recommendation 2002) i Međunarodnog komiteta za promociju i razvoj zadruga (COPAC) je da države u zakonu koriste datu definiciju. Prema univerzalno prihvaćenoj definiciji zadruga je „autonomna asocijacija lica dobrovoljno udruženih sa ciljem da zadovolje zajedničke ekonomske, socijalne i kulturne potrebe i aspiracije, kroz zajednički posedovano, demokratski kontrolisano preduzeće" (ICA, 1995). Deklaracija o zadružnom identitetu navedenu definiciju proširuje sa zadružnim vrednostima i principima. Navedene komponente identiteta zadruge (definicija, principi i vrednosti) jesu kamen međaš za determinisanje zadruga kao posebnih privrednih lica i njihovo razlikovanje od drugih subjekata. Data definicija zadruge sadrži brojne karakteristike, a nužno je istaći ove: „1) ona je samostalna, tj. autonomna i nezavisna od vlasti, 2) ona je udruženje lica, po pravilu - fizičkih lica, ali u određenim slučajevima i pravnih lica, u svojstvu zadrugara, 3) ona je organizacija otvorena za nove članove, 4) u nju se lica udružuju dobrovoljno, što znači da se ulazi i izlazi slobodnom voljom, 5) članovi zadruge u njoj zadovoljavoju svoje ekonomske, socijalne i kulturne potrebe, što znači da se dominantno osnivaju radi zadovoljenja potreba svojih članova, 6) ona je zajednički posedovano i demokratski kontrolisano preduzeće, što znači da počiva na zadružnoj svojini i demokratskim osnovama, 7) ona je preduzeće u smislu da je organizovani entitet koji funkcioniše na tržištu, nastojeći da svoje članstvo opslužuje efikasno i efektivno“" (Dabić, 2011).

b. Zadružne vrednosti. Da bi zadruga efikasno bila organizovana i poslovala potrebno je da poštuje i primenjuje zadružne vrednosti i principe, a koje utvrđuje ili redefiniše Međunarodni zadružni savez. Prilikom osnivanja saveza 1895. godine (pola veka nakon osnivanja prve potrošačke zadruge u Ročdelu) bilo je 13 država članica, a među njima i Kraljevina Srbija. Međunarodni zadružni savez (MZS), kao najznačajnija globalna zadružna institucija danas čine 105 država sa preko milijardu zadrugara i oko 3 mil. zadruga, a zapošljavaju preko 280 mil. ljudi (10\% od ukupnog broja zaposlenih), pri čemu ostvaruju ukupan prihod godišnje od 2,1 biliona američkih dolara (Zakić, Nikolić, 2019). Na osnovu analize pravnog položaja zadruge teorija je vremenom formulisala načela osnivanja i poslovanja zadruge, tj. zadružna načela (zadružne principe). Ona su na međunarodnom planu ozvaničena u tzv. međunarodna načela, preko značajnih međunarodnih dokumenata, u okviru Međunarodnog zadružnog saveza. Na jubilarnom XXXI Kongresu Međunarodnog zadružnog saveza (ICA) održanom u Mančesteru (1995) definisan je pojam zadruge i redefinisane zadružne vrednosti i principi. „Jačanje snage Međunarodnog zadružnog pokreta, u cilju njegovog aktivnog doprinosa harmonizaciji interesa različitih grupa ljudi organizovanih kao potrošači, štediše ili investitori, omogućeno je preciznim definisanjem zadružnih vrednosti i principa za XXI vek“ (Marković, 2007). Zato, „poštovanje zadružnih principa i vrednosti jedan je od ključnih preduslova za uspešno funkcionisanje zadruga" (Mitrović, 2016). Te vrednosti su: samopomoć, samoodgovornost, demokratija, jednakost, pravednost i solidarnost. Zadruga u svom poslovanju, pored osnovnih drži se i etičkih vrednosti: poštenje, otvorenost, društvena odgovornost i briga za druge.

c. Zadružni principi. Zadružna načela, odnosno principi, predstavljaju smernice, tj. uputstva na osnovu kojih zadruge u praksi primenjuju zadružne vrednosti. Treba istaći da inoviranje elemenata identiteta zadruge (definicije, vrednosti i principa) rezultira modernizacijom zadružnog sektora i jačanjem njegovih aktivnosti. Stoga, poslednja (treća) generacija zadružnih principa MZS redefinisana je na Kongresu u Mančesteru (1995) i obuhvata sledeće principe: dobrovoljno i otvoreno članstvo; demokratska kontrola od strane zadrugara; ekonomsko učešće zadrugara; autonomija i nezavisnost; obrazovanje, obuka i informisanje; međunarodna saradnja i briga za zajednicu. Zadružni principi u čl. 4, st. 3 Zakona o zadrugama (2015) Srbije, zapravo su međunarodni zadružni principi. Dakle naš zakonodavac nije razradio principe MZS u vidu zadružnih načela, što znači da je ove principe preuzeo onako kako su dati od strane MZS. Zadružni principi definisani od strane MZS „su važan instrument harmonizacije i unifikacije zadružnog prava na nacionalnom i međunarodnom planu i predstavljaju osnovu izgradnje uniformne zadružne prakse. Predstavljaju značajni element pravne sigurnosti zadrugarstva" (Vitez, 2018). Treba istaći da zadružne vrednosti i principi nisu značajni samo po tome što jasno ukazuju na zadružni identitet, već pre svega što „sopstvena korist mora postati i ostati osnovni motiv udruživanja proizvođača u zemljoradničku zadrugu, ali istovremeno i pojedinačnih zadruga u složenu zemljoradničku zadrugu“ (Gulan, 2019). U tom kontekstu nije tajna da dansko čudo (ova skandinavska zemlja od izvoza hrane prihoduje čak 20 milijardi $€$ ) počiva na dobro organizovanim zadrugama, odn. principima na kojima počiva dansko 
zadrugarstvo. Tri su osnovna principa (pravila): „Prvo je da kooperativa funkcioniše po principu „jedan farmer - jedan glas", bez obzira na veličinu farme; drugo, da su zadruge u zajedničkom vlasništvu svih kooperanata, koji na kraju godine na godišnjoj skupštini odlučuju kako će usmeriti profit, i treće da farmerima njihova krovna udruženja garantuju otkup celokupne poljoprivredne proizvodnje. Ova tri principa gotovo da se nisu menjala od osnivanja Zadružnog pokreta Danske, krajem XIX veka" (Agropress, 2020). Međutim, u Srbiji identitet prave zadruge je velika nepoznanica za veći deo svih poslenika u našem zadrugarstvu, jer su rezultati istraživanja (ankete) ukazali na poražavajuće činjenice. Tako, „veoma je indikativno da još veći deo direktora zadruga $(82,3 \%)$ ne poznaje međunarodne zadružne principe, a od onih koji su dali delimično tačno odgovore nijedan nije znao više od tri od ukupno sedam principa. Zadrugari, koji obavljaju neku od upravljačkih funkcija u zadruzi, takođe slabo poznaju obeležja identiteta zadruge: samo $26,6 \%$ znalo je najviše tri od ukupno deset zadružnih vrednosti, a tek $22,8 \%$ njih najviše tri od ukupno sedam zadružnih principa" (Ševarlić, Zakić, 2012). Dakle, da bi svaka zadruga bila uspešna potrebno je da zadružne principe poznaju svi, počev od direktora pa do svakog člana zadruge.

\section{Sadašnje stanje i moguće novine u zadrugarstvu} Srbije / Current situation and possible novelties in Serbian cooperatives

Zadrugarstvo u Srbiji uglavnom se razvijalo preko zemljoradničkih zadruga, zapostavljajući ostale zadružne oblike, ali i taj oblik nije dovoljno razvijen, tako da još uvek nije u dovoljnoj meri i u funkciji održivog razvoja ruralnih područja. Pitanje zadruga kao posebne vrste privrednih organizacija u Srbiji uređeno je Zakonom o zadrugama iz 2015. Ovaj zakon ima pozitivan trend u približavanju zakonodavstvu Evropske zadruge. Novine ovog zakona „se odnose: na iznos osnovnog kapitala; na to da ulozi zadrugara ne moraju biti jednaki, čime se olakšava i ubrzava kapitalizacija zadruga; da se ulog zadrugara ne može prenositi pravnim poslom, čime se sprečavaju zloupotrebe i izigravanje zakona; pojednostavljen je način osnivanja i organizovanja zadruga - mogu ih osnivati najmanje pet poslovno sposobnih fizičkih lica; na to da su zadruge rasterećene obaveze osnivanja obaveznog rezervnog fonda i zarobljavanja sredstava u njemu, čime se povećeva kapital u zadružnom sektoru (Mitrović et al., 2019), a data je mogućnost osnivanja novih zadruga, uključujući specijalizovane i složene.

Međutim, pored toga što je Zakon o zadrugama (2015) doneo određene novine (unapređenja), ipak ima i nedostatke. Naime, da bi se pravna regulativa srpske zadruge približila pravnoj regulativi Evropske zadruge, potrebno je: revidirati stav o zadruzi; da članovi mogu biti i fizička i pravna lica (u ograničenom broju pravna lica mogu biti članovi zadruge), čime bi se pojačala funkcija samofinansiranja zadruge, a i podigao nivo stručnosti poslovanja i upravljanja zadrugom; relativizovati efekat principa „jedan član - jedan glas“, zapravo - urediti pravo zadruge na više glasova u skupštini (do određenog nivoa) ukoliko je član u zadrugu uneo veći ulog, čime bi se obezbedila njegova veća zainteresovanost za poslovanje zadruge, samim tim i jačanje funkcije samofinansiranja zadruge i dr.; urediti mogućnost da zadrugom upravljaju pored zadrugara još i kooperanti zaposleni u zadruzi, kao i treća lica (ali u ograničenom broju), a sve u cilju da se poveća demokratičnost u zadruzi i da bi se došlo do povećanja efikasnosti privređivanja zadruge. Pored toga, važeći Zakon o zadrugama vratio je duh zadrugarstva, ali nije zadružnu imovinu. To je najznačajnija stavka koja se pominje u važećem Zakonu o zadrugama. Zatim, ključni nedostatak ovog zakona je odsustvo mogućnosti osnivanja štedno-kreditnih zadruga, koji su najvažniji izvor finansiranja zadruga u EU. Dalje, urediti mogućnost osnivanja posebno ženskih zadruga (ICA ima poseban komitet za ovu vrstu zadruga). Podsećamo, znatan broj žena ostao je bez posla u procesu tranzicije. Isto tako, posebno imenovati u Zakonu o zadrugama - zadruge za turizam (ZOZ 2015, čl. $10)$, jer su retko uključene u poljoprivredne zadruge. Takođe, penzioneri i staro stanovništvo u ruralnim područjima imaju veliku potrebu za zdravstvenim i potrošačkim zadrugama (mada su imenovane u važećem Zakonu o zadrugama).

Treba istaći da je u Srbiji „registrovano oko 4500 zadruga, od kojih su samo 2500 aktivne, a 2000 zemljoradničke i koje imaju 35000 zadrugara i više od 100.000 kooperanata" (Krkobabić, 2020). Danas je za razvoj zadrugarstva zainteresovana i država, autonomne pokrajine i jedinice lokalne samouprave [ZOZ, čl. 12]. Od pokretanja akcije „500 zadruga u 500 sela“, 2017. do sredine 2020. vraćen je duh zadrugarstva u Srbiji i osnovano je 720 zadruga. Ukazujemo da prvi put u istoriji zadrugarstva na prostorima Srbije, država direktnim investicijama i bespovratnim sredstvima pomaže oživljavanje zadrugarstva. Godine 2017. određeno je oko 200 mil. dinara (1,7 mil. $€$ ), za 2018. zadrugari su dobili 825 mil. dinara (oko 7 mil. €), a za period 2018-2020. planirano je da ta suma dostigne 25 mil. $€$ (Gulan, 2020).

Razvoj zadrugarstva od strane države (sadašnji i budući) stvara potrebu i za jačanjem sistema 
zadružne revizije, u cilju sprečavanja zloupotreba, provere da li su zadruge radile po zadružnim principima, kao i unapređivanje rada zadruga i dr. $\mathrm{Na}$ kraju, Srbiji kao agrarnoj zemlji za održivi model razvoja zadrugarstva potrebna je modernizacija zadrugarstva, ali ne samo povećanjem broja zadruga, već i podizanjem njihovog kvaliteta - edukacija kadrova za vođenje poslovanja zadruga, omasovljavanje članstva i kvalitetna pravna regulativa, koja će se približiti zadrugarstvu EU.

\section{ZAKLJUČAK / CONCLUSION}

Zadrugarstvo u Srbiji ima dugu tradiciju postojanja, ali zadružni sektor nije razvijen, već je u privrednoj strukturi marginalizovan u poređenju sa razvijenim zadružnim sektorom u zemljama EU. Analiza u radu je pokazala da Srbija ima visok stepen ruralnosti $(85 \%)$, kao i to da je ona agrarno-ruralna zemlja sa još uvek nedovoljno razvijenom poljoprivredom i sa izrazito zapuštenim ruralnim područjima. Otuda potreba da zadruge ponovo postanu ne samo ekonomsko, već i kulturno, socijalno i vaspitno središte razvoja sela. Zadruge treba da postanu "stožer" za opstanak i povratak ljudi (mladih) iz gradova i inostranstva u sela (uz bolju infrastrukturu, vitalne institucije, internet). Povratak na selo ne mora biti obrada zemlje, već nepoljoprivredni život visokoobrazovanih, kreativnih i talentovanih ljudi. Opstanak i povratak na selo za Srbiju je strateški značajno, jer sela se decenijama prazne i nestaju. Nema sumnje, u ruralnim područjima Srbije poljoprivreda treba da se intenzivno razvija, s obzirom na buduću tražnju za hranom u zemlji i svetu. Poljoprivreda, sa stanovišta budućeg razvoja ruralnih područja, neće biti jedina koja će nuditi zaposlenje ruralnoj populaciji, jer budući koncept razvoja istih treba da bude „ruralna ekonomija“, koja će obuhvatiti pored poljoprivrede i nepoljoprivredne delatnosti. Zapravo, značaj poljoprivrede će ići sve više u pravcu zaštite sredine i prirodnog nasleđa.

Zadrugarstvo u Srbiji danas sve više dobija na značaju. Taj argument ide u prilog reafirmaciji zadružnog pokreta, pre svega zemljoradničkog zadrugarstva, kao najefikasnijeg leka protiv opasne demografske bolesti odumiranja sela. Rezultati istraživanja ukazuju na izrazite promene u broju i strukturi ruralnog, odn. poljoprivrednog stanovništva. Prisutno je intenzivno smanjenje broja poljoprivrednog stanovništva. Usled procesa deagrarizacije, depopulacije i deregulacije, efekti poljoprivredne proizvodnje će se ubuduće znatno smanjivati. Takođe, analizom stanja zadrugarstva uopšte i posebno zemljoradničkog zadrugarstva u Srbiji zaključujemo da su neophodne promene na dva koloseka. Prvi je da se nastave započete akcije od strane države (revitalizacija ovog značajnog sektora privrede), drugi je uvažavanje odrednica identiteta zadruge (što je integralni deo važećeg Zakona o zadrugama) i usklađivanje sa međunarodnom zadružnom legislativom, vodeći računa o nacionalnim interesima u lokalnim i ruralnim područjima. Na kraju, treba istaći da je u Srbiji osnovan veliki broj zadruga, preko 700 i prihvaćene su od onih koji će biti njeni članovi, ali to nije dovoljno. Potrebno je napraviti sledeće korake: obezbediti edukaciju kadrova za vođenje poslovanja zadruga, omasovljavanje članstva i kvalitetnu pravnu regulativu, koja će se približiti zadrugarstvu EU.

\section{LITERATURA / REFERENCES}

[1] Bogdanov, N., Babović, M. (2014). Radna snaga $i$ aktivnost poljoprivrednih gazdinstava. Beograd: RZS.

[2] Borzaga, C., Galera, G. (2020). Promovisanje zadruga u stvaranju boljeg sutra. Preuzeto 30.09.2020. sa: www.euricse.eu/wp-content/

[3] Council Regulation (EC), No 1435/2003, july 22nd on the Statute for a European Cooperative Society (SCE): Uredba o Statutu Evropske zadruge, U: Jurić, D. (2006). Evropska zadruga. Pravo i porezi, 6/2006, str. 58-67.

[4] Dabić, Lj. (2011). Zadruge kao poseban pravnoorganizacioni oblik (uporednopravni pristup). Pravo i privreda, 4-6, 126-150.

[5] Gulan, B. (2019). Reindustrijalizacija agrara Srbije: Genocid nad seljakom, Portal Makroekonomija, preuzeto 3.4.2020. sa:

https://www.makroekonomija.org/poljoprivreda/

[6] Gulan, B. (2019). Savremeno zadrugarstvo u Srbiji (Naučna konferencija „Savremeno zadrugarstvo u Srbiji“', Knić, 2019). Portal Makroekonomija, preuzeto 10.4.2019. sa:

https://www.makroekonomija.org/poljoprivreda/

[7] Gulan, B. (2020). Zadrugarstvo u Srbiji od osnivanja do danas 2018. Portal Makroekonomija, preuzeto 8.10.2020. sa:

https://www.makroekonomija.org/poljoprivreda/

[8] Hanrÿ, H. (2001). Guidelines For Cooperatives Policy And Legislation (Guidelines For Cooperatives Legislation). Review of International Cooperation, 94 (2), Seul, p. 66.

[9] Humphreys, J. S. \& Rolley, F. (1991). Health \& health care in rural Australia: a literature review. Armidale. University of New England. Department of geography and planning.

[10] ILO Recommendation on the promotion of cooperatives No. 193 (2002). Preuzeto 7.10.2009 sa: http://www.ilo.org/dyn/normlex/en/ 
[11] The International Cooperative Alliance: Statement on the Cooperative Identity. (1995). ICA, News, No. 5-6/1995, p. 3.

[12] Krkobabić, M. (2020). Kako zadruge dočekuju svoj dan. RTS, 3. 7. 2020, 15:44 - 16:00.

[13] Marković, K. (2007). Poljoprivredno zadrugarstvo u Republici Srbiji - stanje i perspektive, Letopis naučnih radova, br. 1, Novi Sad: Poljoprivredni fakultet, str. 114-121.

[14] Mitrović, A., Mitrović, S., Denić, N., Mitrović, Lj. (2018). Zemljišni i ljudski resursi u funkciji ruralne održivosti u Srbiji, Ecologica, 25(90), 444-450.

[15] Mitrović, Lj., Mitrović, A. i Mitrović, S. (2019). Zadruge u funkciji održivog razvoja Srbije, Ecologica, 26(93), 49-53.

[16] Mitrović, S. (2016). Doprinos poljoprivrede u razvoju Srbije, doktorska disertacija. Lešak: Poljoprivredni fakultet Univerziteta u Prištini.

[17] Molnar, D. (2010). Koncept kreativnih gradova iz ekonomske perspektive, Kultura, br. 128, 86-112.
[18] Popis poljoprivrede 2012. Poljoprivreda u Republici Srbiji. (2013). Beograd: Republički zavod za statistiku (RZS).

[19] Ševarlić, M., Zakić, Z. (2012). Strategija razvoja zemljoradničkih zadruga u Republici Srbiji (Radna verzija). Beograd: Društvo agrarnih ekonomista Srbije, str. 22.

[20] Tomić, D., Gulan, B., Kosov, R. (2017). Vodič kroz zadrugarstvo Srbije. Beograd: Institut za ekonomiku poljoprivrede.

[21] Tri osnovna pravila za dobro poslovanje zadruge, AGROPRESS, preuzeto 10.3.2020. sa: www.agropress.org.rs/lat/

[22] Vitez, M. (2018). Neki aspekti korporativnog upravljanja zadrugom. Pravo - teorija i praksa, 35(1-3), 18-35.

[23] Vitez, M. (1998). Zadruga i naše privredno pravo, Pravo - teorija i praksa, 15(5-6),

[24] Zakić, V., Nikolić, M. (2018). Finansijska podrška države zadrugama u Srbiji, Škola biznisa, No. 1, 158-174.

[25] Zakon o zadrugama - ZOZ (2015), Službeni glasnik RS, br. 112/15. 